\title{
80 let České kardiologické společnosti
}

\author{
Roman Čerbák \\ Centrum kardiovaskulární a transplantační chirurgie, Brno, Česká republika
}

Adresa: prof. MUDr. Roman Čerbák, CSc., Centrum kardiovaskulární a transplantační chirurgie, Pekařská 53, 65691 Brno, Česká republika, e-mail: roman.cerbak@cktch.cz

V tomto čísle Cor et Vasa bude zmíněno mnoho význačných kardiologů, kteří nevšedním způsobem ovlivnili Českou kardiologickou společnost, at již po stránce odborné, morální nebo způsobem obojím. Rád bych připomněl dva z nich, kteř́i vstoupili i do mého života a natrvalo mne poznamenali.

První z nich je profesor Pavel Lukl. Noblesní člověk, vysokých morálních kvalit, který kromě odborných znalostí měl i schopnosti organizační, pedagogické a manažerské. Po druhé světové válce nastoupil na novou lékařskou fakultu v Hradci Králové. Tato fakulta byla zř́zena jako pobočka fakulty Univerzity Karlovy zvláštním dekretem prezidenta Beneše dne 13. 10. 1945. Profesor Lukl se stal přednostou I. interní kliniky. V roce 1947, po návštěvě americké lékařské delegace, mu přední americký kardiolog Paul Dudley White nabídl stipendium ve Spojených státech. Prof. Lukl se vrátil domů plný nových myšlenek, které uváděl v život na své klinice. Provedl např́íklad v Hradci Králové první katetrizaci srdce a s prof. Bedrnou stál u základů kardiochirurgie. ${ }^{(1)}$

Dne 15. 8. 1951 byla tato lékařská fakulta, pobočka Univerzity Karlovy, „rozkazem“ jiného prezidenta zrušena a zř́zena Vojenská lékařská akademie. Tato akademie sice znamenala větší materiální podporu školy, ale na druhé straně vojenskopolitické totalitní řízení s pomocí sovětských poradců rozhodně nepřispívalo univerzitnímu duchu. Po této změně poměrů profesor Lukl odchází, jak také jinak, a 1. 6. 1953 nastupuje jako přednosta I. interní kliniky Lékařské fakulta Univerzity Palackého (LF UP) v Olomouci. Na této cestě ho doprovází řada spolupracovníkủ a také jeho žák, MUDr. Jiří Endrys. I v Olomouci přivádí prof. Lukl kliniku na vysokou úroveň. Přednáší také na zahraničních akcích v USA, Japonsku, Indonésii, Indii, Dánsku, Itálii, Francii a Španělsku. V roce 1968 je hostujícím profesorem v Dánsku. Po sovětské okupaci v roce 1968 musí profesor Lukl LF UP opustit, jak také jinak. V letech 1971-1977 pracuje v Lázních Teplice nad Bečvou jako konsiliář, kde užšímu kruhu lékařů přednáśí na 25 souhrnných přednášek

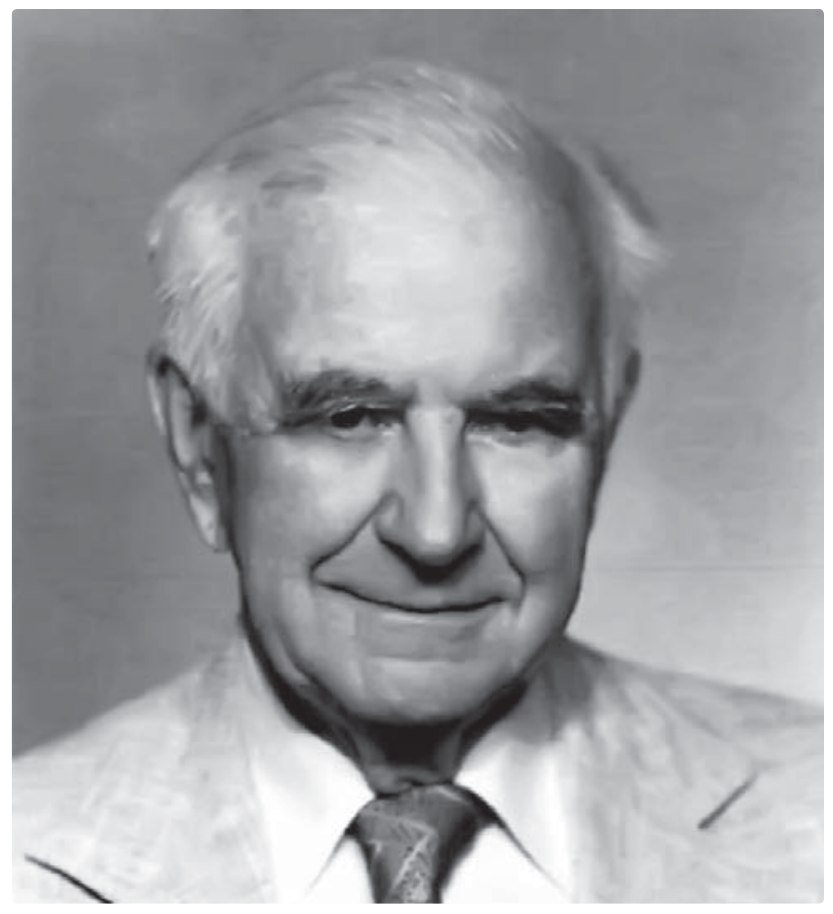

Obrázek 1 Prof. Pavel Lukl

z oboru kardiologie. Na LF UP v Olomouci se vrací až po revoluci v roce 1989, kdy ho děkan jmenuje vedoucím spojených kateder vnitřního lékařství. Umírá 14. 12. 1995.

Uvedené události by bohatě stačily zaplnit životy několika lidí. Ne tak u pana profesora Pavla Lukla. Během svého života stačil napsat vysoce ceněnou Učebnici vnitřního lékařství vydanou v roce 1955 (reedice v letech 1960, 1965, 1971), stát se předsedou Československé kardiologické společnosti v letech 1959-1971 a předsedou Evropské kardiologické společnosti v období let 1968-1970. V roce 1964 uspořádal v Praze IV. kongres Evropské kardiologické společnosti. (2)

Pana profesora Lukla jsem poprvé potkal na Evropském kardiologickém kongresu v Praze v roce 1964. Byl jsem tehdy mladý sekundář na I. interní klinice $\mathrm{v}$ Brně a účast na takovém kongresu byl zázrak. Netušil jsem, jak velké 


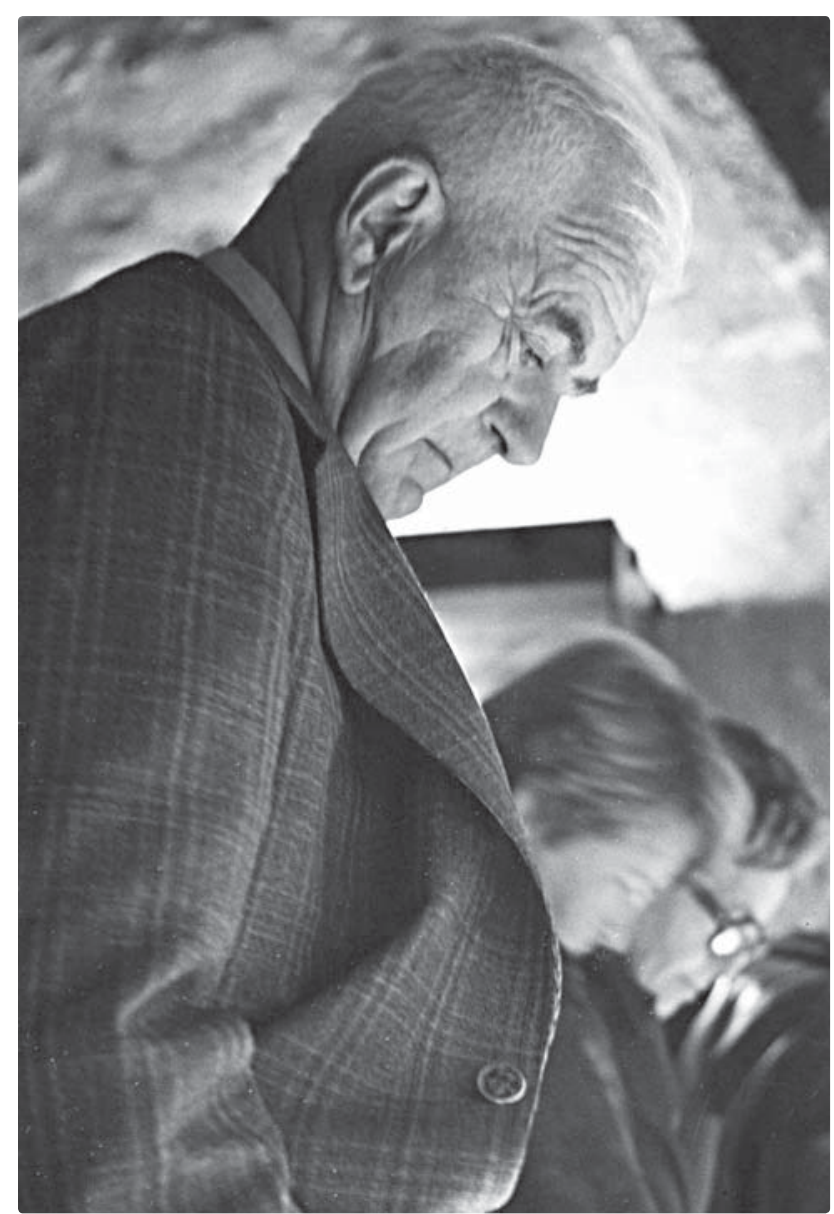

Obrázek 2 Prof. Lukl na kardiologickém symposiu na počátku 90 . let

úsilí musel organizátor této evropské akce vyvinout, aby se mohla uskutečnit v tehdejším socialistickém Československu. Pak jsem pana profesora potkával na některých kardiologických akcích, kterých se zúčastnil. Přiznávám se, aktivně jsem ho vyhledával, protože jsem znal jeho dosavadní život. Vyptával jsem se na kardiologii a pan profesor mi během krátkých rozprav odpovídal a současně mi ozřejmoval svou hierarchii životních hodnot. Bylo to pořadí, které jsem tehdy vděčně přijímal a později se podle něj řídil. Rád vzpomínám na jeho moudré rady. Měl jsem ještě jednu možnost potkat pana profesora při př́ležitosti arytmologického symposia, které uspořádal jeho syn Jan v Olomouci v roce 1995. Netušil jsem, že je to setkání již poslední.

Byl bych nerad, kdyby moje vzpomínky budily dojem blízkého vztahu. Pan profesor si mě nepamatoval, sotva mě poznal, já však na něho budu vzpomínat do konce života.

Prof. Philip A. Poole-Wilson napsal: „His contribution to cardiology, the European Society of Cardiology and humanity will not be forgotten." "(3)

Vzpomínku na pana profesora Pavla Lukla nemohu ukončit jinak než vzpomínkou na jeho syna Jana. Sblížili jsme se ve výboru České kardiologické společnosti v devadesátých letech. V paměti jsem měl zafixováno jméno jeho tatínka, a tak jsem mu neustále ř́kal Pavle. Zpočátku to trpělivě snášel, později se však ohradil a opravil mě: „Jmenuji se Jan“. Když ani to nepomáhalo, zamyslel se a řekl mi:
„Když to jinak nejde, budiž, vlastně jsem Jan Pavel druhý.“ Zaradoval jsem se. I když jsem Jana tak často neoslovoval, přece jsem někdy neodolal a měl jsem př́jemný pocit při vědomí, že tímto jménem oslovuji i tatínka a že Svatému otci to určitě nevadí.

Když jsem v těchto dnech pátral v literatuře, na co jsem ještě zapomněl, našel jsem v Intervenční a akutní kardiologii zajímavou informaci, že profesor Jan Lukl dostal při křtu dvě jména Jan a Pavel. Tatínek zřejmě tušil, jaké obtíže budou synka životem provázet. ${ }^{(4)}$

Druhým kardiologem, o kterém bych se rád zmínil při příležitosti 80. výročí založení České kardiologické společnosti, je docent MUDr. Jiří Endrys. S předchozím kardiologem má mnoho společného: široký obecný vědomostní rozhled, hluboké odborné znalosti, vzácné pedagogické schopnosti i mezinárodní proslulost. Vlastně ještě víc: když profesor Lukl odcházel v roce 1956 z Hradce Králové do Olomouce, provázel ho i Jiř́i Endrys, jeho žák. Centrem jeho zájmu byl kromě kardiovaskulární diagnostiky i výzkum, patofyziologie a vývoj nových metod. V Olomouci se doktor Endrys zdržel jen krátce, pracoval zde v letech 1956-1958. Jinak celý svůj odborný život strávil v Hradci Králové, nepočítáme-li krátké, i když četné zastávky $\mathrm{v}$ mnoha městech Evropy, ve kterých živě předváděl invazivní diagnostické metody v kardiologii, které vyvinul nebo modifikoval. A nelze také pominout déletrvající pobyty v Chest Hospital v Kuwaitu, kde založil a rozvíjel obor invazivní a intervenční kardiologie. ${ }^{(5)}$

V šedesátých letech minulého století jsem se učil srdečním katetrizacím, a tak jsem pana doktora Endryse nemohl minout. Byly to krásné cesty do Hradce Králové. Dopoledne nám Jiří Endrys předváděl srdeční katetrizaci, včetně pro mě tehdy nedostupné transseptální katetrizace, a v odpoledních, nezřídka i večerních hodinách, $\mathrm{v}$ mimořádně cenných diskusích nás zasvěcoval do tajů invazivní kardiologické diagnostiky. Byl to dotek vysoké profesionality spojené s neobvyklým zaujetím pro věc. Nikdy před tím ani potom jsem něco podobného nezažil. Jiří Endrys nelitoval námahy ani času, aby předal svým žákům maximum svých znalostí. Poznamenal mě svým přístupem a když slyším slovo „učitel“, vždy si vzpomenu na něj. Cesty za ním do Hradce Králové znamenaly pro mě cestu do hájemství poznání a pravdy, kterých si vážil nade vše. Velmi dobře si vzpomínám na jeho nelibost, a to je slabé slovo, když se na pořad dne a diskuse dostal lékař, který si upravoval výsledky své vědecké práce podle svých privátních předpokladů. Od doktora Endryse se dočkal tak odsuzujícího rozsudku, jako by zabil člověka. Byla to velmi účinná škola života, nad jiné dobrá. Byly to cesty časem i rozsahem neohraničené.

V roce 1979 jsem se spolu s doktorem Endrysem zúčastnil založení pracovní skupiny „Invazivní kardiovaskulární diagnostika“. Iniciátory byli pozdější profesoři Juraj Fabián z IKEM a spolu s ním Miloslav Kučera z VFN na Karlově náměstí a Milan Šamánek z Dětského Kardiocentra v Motole, z ÚKOK v Bratislavě pak MUDr. Ján Zelenay. ${ }^{(6)}$ Slavnostní vznik pracovní skupiny jsme oslavili 9. listopadu 


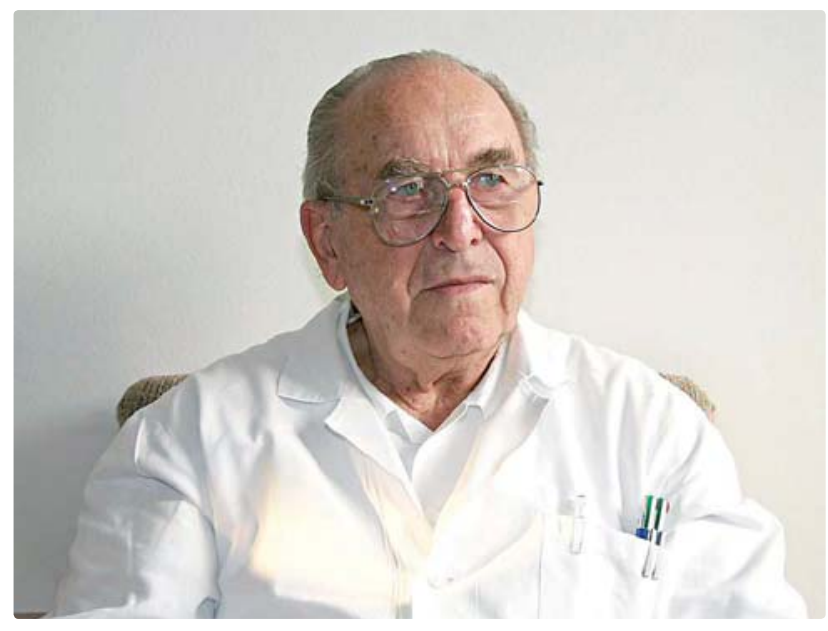

Obrázek 3 Doc. Jiří Endrys

1979 v malé vesnici Cikháj na Českomoravské vysočině. ${ }^{(7)}$ A bylo co oslavovat. Dnešní čtenář už asi nepochopí, proč bylo nutné pracovní skupinu kardiologické společnosti ustavovat pod hlavičkou chirurgické společnosti. Nebylo to jinak schůdné, vysvětlil nám Juraj.

V roce 1983 jsem byl hospitalizován na chirurgické klinice v Hradci Králové pro cholelithiázu. Samozřejmě, že má první cesta vedla za Jiřím Endrysem, který v té době pracoval jako interní konsiliář na chirurgii. Zavedl mě do svého inspekčního pokoje, poskytl mi klíče a první vydání Heart Disease Eugena Braunwalda. Odjižděl na zahraniční cestu a řekl mi, at se chovám jako doma. Z nepř́íjemné události se stal mimořádně př́ijemný pobyt. Když jsem byl propuštěn domů moc jsem toužil půjčit si Braunwaldovu publikaci. Knížka byla pro mě zjevením, nevídaným $\mathrm{v}$ té době. Věděl jsem, že na interní klinice nemocnice pracuje Endrysova dcera Lada, které jsem se zeptal, zda si $\mathrm{v}$ tatínkově nepř́tomnosti mohu půjčit na krátkou dobu jeho knihu. Odpověděla, že samozřejmě ano.

Jiří byl pak ale velmi rozčilen. Jak jsem si mohl, bez jeho výslovného svolení půjčit tak cennou knihu, to má za to, že mi poskytl pohostinství, host se nikdy nechová takto a podobně. Myslel to smrtelně vážně, mně se to ale mimořádně líbilo, protože jsem věděl, že to patří k jeho genetické výbavě a že má pravdu.

Tomuto svému učiteli zůstanu navždycky vděčen za jeho přístup $\mathrm{k}$ životu, profesionalitě i $\mathrm{k}$ pravdě.

Recenzoval jsem jeho knížku „Invazivní hemodynamické metody“, kterou vydal v nakladatelství Nucleus v Hradci Králové a oponoval jeho habilitační práci, kterou mohl obhájit až po pádu komunismu, jak také jinak.

Jsou to však jen malé splátky na velký dluh, který vůči němu cítím.

Docent Jiří Endrys řekl při udělení zlaté medaile Václava Libenského:

„Dalším mým velkým učitelem byl prof. Pavel Lukl, jeden z posledních klinikư, kteří ještě zvládli celou interní medicínu. Nezapomenutelné byly jeho vizity s bezprostředním kontaktem i s nejmladšími členy teamu většinou bez dlouhého fluor

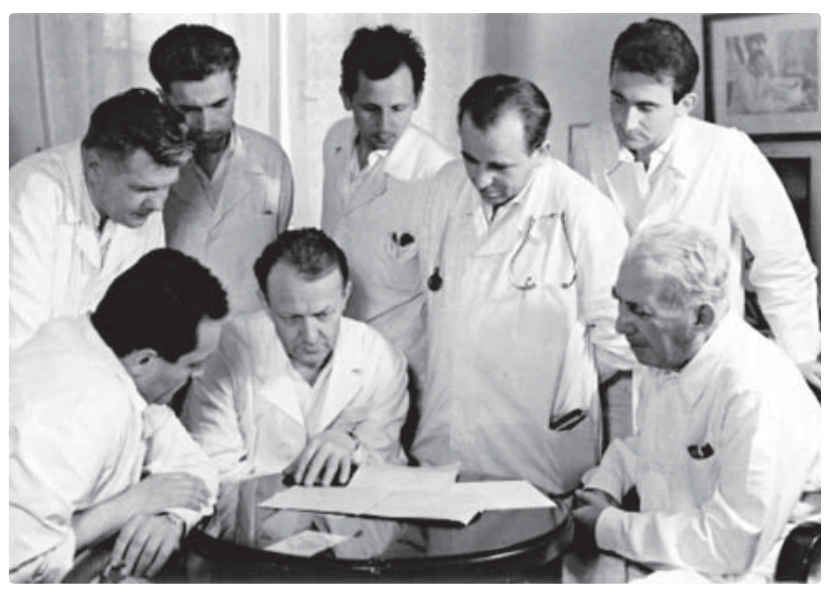

Obrázek 4 Známá fotografie kardiologicko-kardiochirurgické skupiny v Hradci Králové na počátku 60. let minulého století

albus. Nemohu zapomenout na nemocnou, u niž se mi fyzikálně nepodařilo lokalizovat bronchopneumonii. Poprosil jsem profesora Lukla, zda by on byl úspěšnější, přičemž jsem držel v ruce snímek tangenciálně tak, aby ho nevidèl. Vyhověl, aniž by žádal drivive si snímek prohlédnout. Jeho individuální výchova mladších lékařư přinesla své výsledky. Mnoho z jeho žáků dosáhlo akademických titulů: Procházka, Černohorský, Groh, Hauftová, Bèlobrádek. Lukl byl podobně jako Fingerland vzor osobni statečnosti a charakteru. Neustoupili politickému nátlaku ani za cenu nuceného vyřazení $z$ aktivní funkce univerzitního profesora a prednosty ústavu“.

Když jsem byl požádán redakcí časopisu Cor et Vasa o článek k 80. výročí České kardiologické společnosti, nebyl mi stanoven ani jeho obsah, ani rozsah. Dlouho jsem nevěděl o čem psát. Až potom zcela náhodou (?) jsem objevil ve svých věcech starou fotografii pana profesora Lukla z jednoho kardiologického symposia. S fotografí přišly i vzpomínky a pozvání na cestu. Neodolal jsem a vydal jsem se na výlet za svými učiteli a vzory. Během cesty jsem si s překvapením uvědomoval, kolik měli oba podobných vlastností, charakterových znaků i zájmů. Ne nadarmo byl mezi nimi vztah učitele a žáka a vlastně zákonitě oba musela přitahovat srdeční katetrizace. Byl to pěkný a radostný výlet, nerad jsem se $\mathrm{z}$ něj vracel. Doufám, že aspoň něco z tohoto potěšení najdou i čtenáři.

\section{Literatura}

1. Informační centrum statutárního města Olomouce; infocentrum@olomouc.eu, aktualizace 1.6.2005, martin.hala@olomouc.eu

2. Zdeněk Fejfar. Česká kardiologie a kardiologové. Praha: Galén, 2001:330.

3. Poole-Wilson PA. Professor Pavel Lukl 1905-1995. Eur Heart J 1997;Obituaries 173

4. Heinc P, Sovová E. K životnímu jubileu profesora MUDr. Jana Lukla, CSc. Interv Akut Kardiol 2004;3:162.

5. Vojáček J. Laudace - Doc. MUDr. Jiří Endrys, CSc. Interv Akut Kardiol 2006;5:44-45

6. Čerbák R. Pracovní skupina "Invazivní kardiovaskulární diagnostika se představuje. ' 80 VI/1. Kardiovaskulární zpravodaj IKEM a Kardiovaskulární sekce České chirurgické společnosti, 1980:88-89

7. Čerbák R. I. celostátní sympozium pracovní skupiny „Invazivní kardiovaskulární diagnostika" v Cikháji dne 9. 11. 1979. Vnitř lék 1980;26:411-2. 